\title{
Coastal Students' Perspectives on Digital Reading Comprehension: A Rasch Model Analysis
}

\author{
Gatot Subroto $^{1}$, Satria Agust ${ }^{2}$, Amartya Angela ${ }^{3}$, Anek Dezar ${ }^{4}$, Della Zahra ${ }^{5}$, Dina Isra \\ Mirarizka $^{6}$, Farizi Rianto ${ }^{7}$, Vitri Rayani ${ }^{8}$, Muhammad Candra ${ }^{9}$ \\ \{ gatot.subroto@umrah.ac.id ${ }^{1}$, satria.agust@umrah.ac.id ${ }^{2}$, amartyaangela55@gmail.com ${ }^{3}$, \\ anekdezhar@gmail.com ${ }^{4}$, dellazhr04@gmail.com ${ }^{5}$, dinaisramira@gmail.com 6 , \\ riantofarizi1313@gmail.com ${ }^{7}$, vitrirayani@gmail.com ${ }^{8}$, m.candra09@gmail.com ${ }^{9}$ \} \\ ${ }^{1,2,3}$ English Education Department, Teacher Training and Education Faculty, Universitas Maritim \\ Raja Ali Haji, Tanjungpinang, Indonesia
}

\begin{abstract}
The purpose of this study was to determine the coastal students' perspective on digital reading comprehension. The study was conducted at Universitas Maritim Raja Ali Haji in the department of English Education in 2021. A descriptive quantitative method using questionnaires was applied to collect data from 70 second-semester students who participated in this exercise. The data collected was analyzed quantitatively using the Rasch model called Winsteps version 3.73 software. The results revealed that most coastal students had a good perception of digital reading comprehension. Furthermore, they believed digital reading greatly improved their reading comprehension than traditional methods.
\end{abstract}

Keywords: Coastal students' perspective, digital reading, reading comprehension, Rasch model

\section{Introduction}

The massive impact of the Covid-19 pandemic has been felt across all sectors, including the economy, politics, governance, health, and education. Many countries across the globe closed down schools to stop the spread of the Covid-19 virus. Therefore, studying from home with the help of online learning became an option for many educational institutions. Online learning is a type of learning in which teachers or lecturers employ technology to provide material and engage with the students through the internet. This phenomenon has had a significant impact on learning in all fields of study, including learning English.

English is among the few internationally recognized and highly spoken languages in the world. Being the world's main social language, the demand for learning the language continues to rise by the day [1]. Consequently, the nature of English in education has changed significantly in the last decade. This has not only resulted in several changes in the way the language is taught and learned but has also led to innovative practices in everyday life. Presently, all people, specifically the students, are expected to be proficient in written and spoken English. Mastering it will not only help them improve their academics and social skills but also make it easy to handle society. 
In Indonesia, English is one of the major foreign languages taught in elementary schools [2]. To master it, students must have the four skills crucial to learning foreign languages. However, most times, students find it challenging to read English texts due to wrong perceptions

Reading is a fundamental skill intertwined with others, such as writing, speaking, and listening. To gain better learning results, students must attempt to read extensively and comprehend the texts. Reading is a method of obtaining information from a text to achieve a better understanding [3]. It helps students to enhance their language and writing skills. Students who enjoy and devote significant time to reading would write well. Therefore, English tutors must have a strong grasp of grammar and vocabulary. This is because the aim of teaching is to develop students' skills and knowledge to read and comprehend texts. Students should also have the ability to alter reading techniques based on the goal of reading, such as skimming and scanning, as well as the ability to take a critical view of the texts' substances [4].

Reading and comprehension are closely related to one another and cannot be separated. Reading involves pronouncing the contents, which can be letters or numbers that are systematically arranged. Reading helps one gain information and knowledge concerning a certain subject besides knowing what is occurring in many parts of the world. If 'reading' converts text into sounds or spoken words, then 'comprehension' implies making sense of all those words. Specifically, reading is the process of making sense of written texts, while comprehension involves making sense of words, sentences, and connected text [5]. Therefore, reading comprehension is known as the ability to grasp and evaluate information in a text [3], [6]. It is impractical for someone to read a text but does not understand the meaning of what is read. This indicates that reading comprehension is a necessary component of understanding the meaning of the text during the reading process. The objective of reading is to understand the written texts, which implies that reading comprehension involves both perception and consideration. Having the background information, vocabulary, grammar knowledge, and other skills helps readers to grasp written materials. Therefore, students need to have excellent reading abilities to excel in their academic endeavors [7]. Other experts indicated that studying the characteristics of efficient reading comprehension is a critical problem for educational psychology [8].

Presently, one of the most extensively used media to promote education is online learning, which allows students to complete studying and demonstration exercises at any time [9]. Some recent studies on online reading methods investigated whether digital reading is more convenient than conventional methods to help with language comprehension [11] and whether the techniques utilized can help with web-based learning [12].

Perceptions of students provide a foundation for learning, comprehending, and directing a certain action or response [13]. Even though they may reach an agreement, everyone might have distinct viewpoints concerning suggesting information and understanding a message. There are various previous studies regarding digital reading comprehension, including [10], [14], [15], [16], [17], [18]. The results from these studies indicate advantages of digital reading have had a meaningful impact on students' comprehension skills. From previous studies, digital reading comprehension has some impacts on students' reading comprehension habits. There are several benefits for students while reading digital texts. These include convenience while understanding the content due to the layout, saving print paper, visible display without poor printing quality, improving online interpretation, making the material easier to follow, and developing material reading abilities.

Reading helps a person to discover the meaning and value included in a text or summarize the meaning. In addition, the term shows that reading entails comprehension. This implies that readers would find it hard to read a text they do not understand [19]. As a result, when one is 
reading, they must attempt to understand and keep the information in their minds. It can be inferred that reading is a process that involves a written text in which readers use their thoughts to understand the material. Additionally, reading is the unification of visual and nonvisual information [5]. As a result, while reading, someone seeks the visual information and combines it with the nonvisual message in their thoughts to produce a creative process (reading).

The ability to read enables learners to participate in comprehension activities such as literal comprehension and contextual and analytical understanding [20]. First, literal comprehension involves the knowledge of notions and facts for a reader to better understand the text's substance. Second, contextual understanding is a summary of the meaning as expressed by readers in their own words. Third, analytical understanding requires the reader to elucidate, evaluate, and gather data. Readers require all these reading comprehension levels to get the information clearly and draw conclusions based on the text's substance. The levels help readers gain useful information, such as a better grasp of the written content and retaining the read text.

Online learning is typically presented as a versatile system of teaching, with flexibility being hailed as a democratizing and appealing feature of this educational system [21], [22]. Institutions are expanding their contributions to online education [23], with e-learning becoming the mainstream that underpins the study flexibility in this environment. However, the primary challenge is determining how to organize guidance through this medium, given the abundance of online language learning materials [24]. The results indicate that online learning significantly improved participants' vocabulary, and students gave positive feedback on the educational assessments they reviewed throughout the semester. Therefore, this study aims to determine the coastal students' perspective on digital reading comprehension.

\section{Method}

This study was conducted at Tanjungpinang, Indonesia, from June to July 2021 using descriptive quantitative techniques [25], [26], [27]. This involved 70 second-semester English Education Department students of Universitas Maritim Raja Ali Haji. The data was collected using a questionnaire to determine the coastal students' perspective on digital reading comprehension. The questionnaire consisted of 20 Likert scale questions with five possible responses ranging from 1 to 5, i.e., strongly disagree, disagree, uncertain, agree, and strongly agree. Furthermore, a Rasch model program called Winsteps [25], [26], [28], [29], [30], [31], [32], [33] was used to examine the data. The Rasch model is crucial in examining individuals in terms of how they respond to items using the person map [26].

\section{Findings and Discussion}

The study used a descriptive method to analyze the data collected from a sample population of 70 students drawn from Universitas Maritim Raja Ali Haji. The students are from diverse backgrounds, both rural and urban areas in Riau Islands Province. Table 1 shows information concerning the participants' demographic information.

Table 1. Participants' demographic information

\begin{tabular}{lll}
\hline Demographic Information & Total Number & Percentage \\
\hline
\end{tabular}




\begin{tabular}{lll} 
Rural & 39 & 55.8 \\
Urban & 31 & 44.2 \\
Total & 70 & 100 \\
\hline
\end{tabular}

Some participants, $27 \%$ of the total, strongly disagree that digital reading comprehension is more practical. The results indicated that $27 \%$ of the participants were students from rural areas. Therefore, it was concluded that some students living in rural areas experienced difficulties during the online learning process, specifically in digital reading comprehension. In contrast, most participants from urban areas agreed that digital reading comprehension is more practical and easier to comprehend.

Figure 1 showed the Cronbach Alpha (KR-20), which measured the interaction between a person and the questionnaire item was 0.85 , while the reliability test of the measured item was 0.99. Besides, the INFIT MNSQ and the OUTFIT MNSQ scores were 1.03 and 1.01. The INFIT ZSTD and the OUTFIT ZSTD scores were 0.0, while the item separation score was 3.77. Therefore, it can be concluded that the study instrument was excellent in the category. The instrument fulfilled the requirement of the Rasch model since it was able to measure the coastal students' perspective on digital reading comprehension.

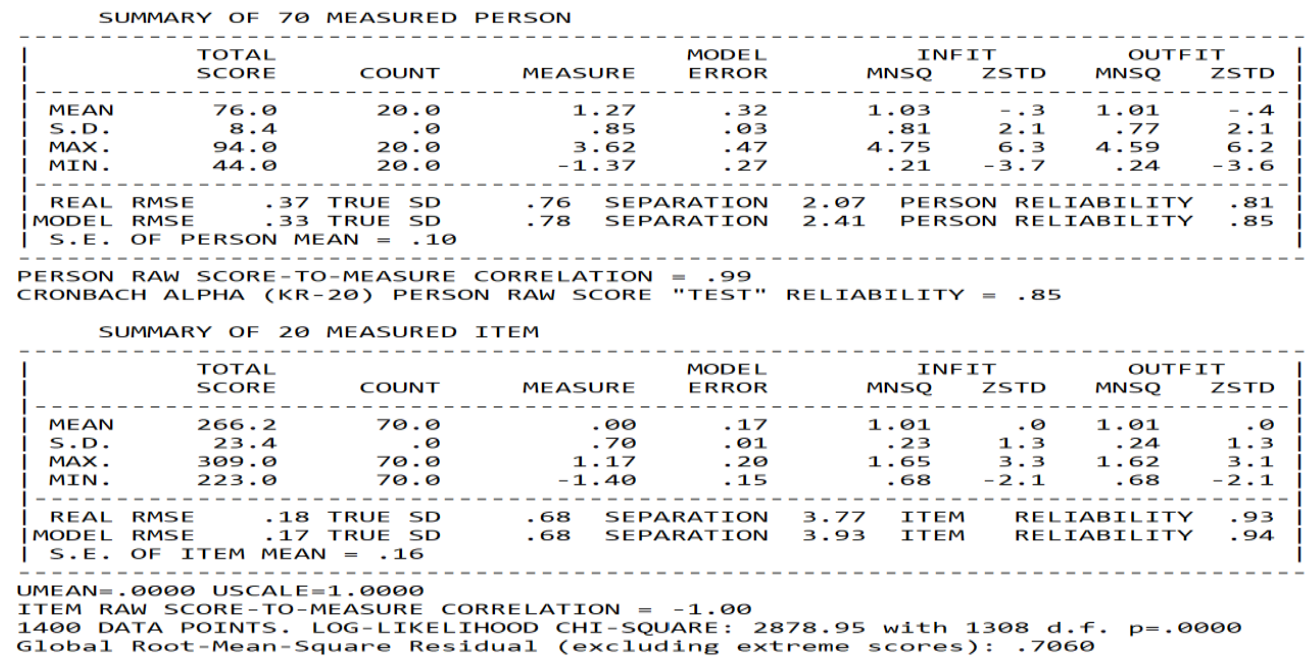

Fig. 1. Person and item reliabilities

Figure 1 indicated that the person reliability result was 0.81 , which can be assumed that this result was already good. The average value of respondents for the person measure was in the resilience scale. The average score - more than 0.0 - indicates the tendency of respondents to choose appropriate statements in the various items [28]. The data above revealed that the person measure value is +1.27 . Also, it was found that the person reliability value was 0.81 , and the item reliability of 0.93 indicated the consistency of the answer from the respondents and that the quality of the item was good. It signifies that the questionnaire belonged to a good category and that the development study instrument fulfilled the Rasch model's requirements [28], [30]. 


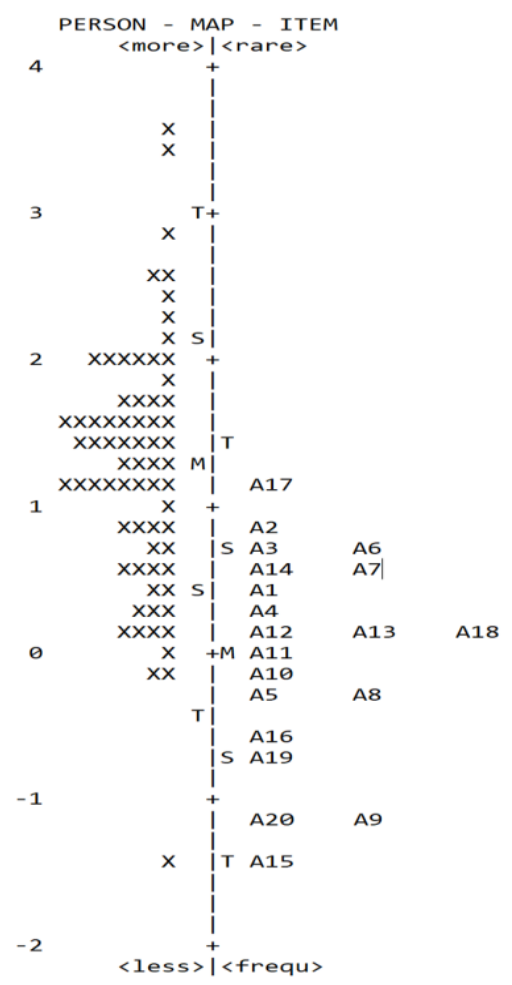

Fig. 2. Wright map of questionnaire items

Figure 2 also showed the rarest and the most frequent items answered by students. The rarest item to answer was item 17, which comprised of "The light from the cell phone screen increases my reading interest." The most frequent item to answer was item 15, i.e., "I find it easier to read online textbooks anywhere and anytime using my phone." Even though item 17 is the rarest item to answer, most students seemed to respond to it differently. Interestingly, the majority of them responded in the affirmative. Furthermore, other items, including A10, A5, A8, A16, A19, A20, A9, and A15, were agreed upon by all students. Therefore, most coastal students had a good perception of digital reading comprehension.

\section{Conclusion}

The study revealed that the digital method significantly affects students' reading comprehension, making most of them embrace this learning method. This makes it the most preferred method of learning as opposed to traditional ways. Furthermore, students believe that digital learning has many advantages with a significant impact on their comprehension skills. The results indicate the need for teachers to be more creative in making the digital reading materials for students to understand better and enjoy digital reading during online learning. Finally, in the online learning process, teachers should promote independent learning to increase students' confidence in reading. 


\section{References}

[1] L. T. Wong and A. Dubey-Jhaveri, English language education in a global world: Practice, issues and challenges. New York: Nova Science Publishning, Inc., 2016.

[2] M. F. Patel and P. M. Jain, English language teaching: Methods, tools \& techniques. Jaipur: Sunrise Publishers \& Distributors, 2008.

[3] W. Grabe and F. L. Stoller, "Teaching and researching reading," in Applied linguistics in action, Second Edi., C. N. Candlin and D. R. Hall, Eds. Routledge, Taylor and Francis Group, 2013, pp. 1-345.

[4] T. Hedge, Teaching and learning in the language classroom. Oxford: Oxford University Press, 2000.

[5] A. P. Johnson, Teaching reading and writing: A guidebook for tutoring and remediating students. United States of America: Rowman \& Littlefield Publishers, Inc., 2008.

[6] J. Oakhill, K. Cain, and C. Elbro, Understanding and teaching reading comprehension: A handbook. 2014.

[7] D. E. Alvermann and A. J. Eakle, "Comprehension instruction: Adolescents and their multiple literacies," Rethink. Read. Compr., no. October, pp. 12-30, 2003.

[8] T. Raphael and E. H. Hiebert, Creating an integrated approach to literacy instruction. Harcourt Brace College Publishers, 1996.

[9] P. Cole, Professional development: A great way to avoid change, vol. 140. Melbourne: IARTV, 2004.

[10] L. W. C. Chen, “Taiwanese EFL learners' perceived use of online reading strategies," IAFOR J. Educ., vol. 3, no. 2, pp. 68-80, 2015.

[11] M. Singhal, "The effects of reading strategy instruction on the reading comprehension, reading process and strategy use of adult ESL readers," The University of Arizona, 1998.

[12] M. M. Chang, "Applying self-regulated learning strategies in a web-based instruction: An investigation of motivation perception," Comput. Assist. Lang. Learn., vol. 18, no. 3, pp. 217-230, 2005.

[13] J. Greenberg and R. A. Baron, Behavior in organizations, 9th Editio. Pearson Hoboken, 2008.

[14] M. Reiber-Kuijpers, M. Kral, and P. Meijer, "Digital reading in a second or foreign language: A systematic literature review," Comput. Educ., vol. 163, no. December 2020, p. 104115, 2021.

[15] P. Delgado and L. Salmerón, "The inattentive on-screen reading: Reading medium affects attention and reading comprehension under time pressure," Learn. Instr., vol. 71, pp. 1-13, 2021.

[16] M. B. Untari, "Learners' perception on their online reading comprehension learning at the English education department of university of Islam Malang," University of islam Malang, 2020.

[17] H. Støle, A. Mangen, and K. Schwippert, "Assessing children's reading comprehension on paper and screen: A mode-effect study," Comput. Educ., vol. 151, no. June 2019, 2020.

[18] P. Pardede, "Print vs digital reading comprehension in EFL: A literature review," JET (Journal English Teaching), vol. 5, no. 2, pp. 77-90, 2019.

[19] N. Farzaneh and D. Nejadansari, "Students' attitude towards using cooperative learning for teaching reading comprehension," Theory Pract. Lang. Stud., vol. 4, no. 
2, pp. 287-292, 2014.

[20] T. Anderson, The theory and practice of online learning, Second Edi. Edmonton: AU Press, Athabasca University, 2008.

[21] T. J. B. Blayone, R. VanOostveen, W. Barber, M. DiGiuseppe, and E. Childs, "Democratizing digital learning: Theorizing the fully online learning community model," Int. J. Educ. Technol. High. Educ., vol. 14, no. 13, pp. 1-16, 2017.

[22] D. Serhan, “Online learning: through their eyes," Int. J. Instr. Media, vol. 37, no. 1, p. 19+, Oct. 2010.

[23] T. Bates, "The 2017 national survey of online learning in Canadian post-secondary education: methodology and results," Int. J. Educ. Technol. High. Educ., vol. 15, no. 29, pp. 1-17, 2018.

[24] A. Alfehaid, "Online English language learning activities and academic achievement: Experiences of first year students and their teachers," Pertanika J. Soc. Sci. Humanit., vol. 27, no. 3, pp. 1557-1572, 2019.

[25] S. Agust and G. Subroto, "Coastal students' tense on grammar tense(s): A Rasch model analysis," Univers. J. Educ. Res., vol. 8, no. 3D, pp. 26-38, 2020.

[26] S. Agust and G. Subroto, "Practicality test of 'stepping the 5 stairs A technique' on grammar for college students: Rasch model analysis," J. Kiprah, vol. 6, no. 2, pp. 3236, 2018.

[27] J. W. Creswell, Educational research: Planning, conducting, and evaluating quantitative and qualitative research, Fifth Edit. USA: Pearson Education, Inc., 2015.

[28] B. Sumintono and W. Widhiarso, Aplikasi pemodelan Rasch pada assessment pendidikan. Cimahi: Trim Komunikata Publishing House, 2015.

[29] S. Agust, G. Subroto, and A. Malik, "Self-actualization measurement on non-English coastal students' achievement: Rasch model analysis," Int. J. Pedagog. Teach. Educ., vol. 2, no. 2, pp. 389-400, 2018.

[30] B. Sumintono, "Rasch model measurements as tools in assessment for learning," vol. 173, no. Icei 2017, pp. 38-42, 2018.

[31] S. W. Chan, C. K. Looi, and B. Sumintono, "Assessing computational thinking abilities among Singapore secondary students: a Rasch model measurement analysis," J. Comput. Educ., vol. 8, no. 2, pp. 213-236, 2021.

[32] W. Purnami, Ashadi, Suranto, Sarwanto, B. Sumintono, and Y. Wahyu, "Investigation of person ability and item fit instruments of eco critical thinking skills in basic science concept materials for elementary pre-service teachers," J. Pendidik. IPA Indones., vol. 10, no. 1, pp. 127-137, 2021.

[33] D. Adams, K. M. Chuah, B. Sumintono, and A. Mohamed, "Students' readiness for elearning during the COVID-19 pandemic in a South-East Asian university: A Rasch analysis," Asian Educ. Dev. Stud., vol. ahead-of-p, no. ahead-of-print, Jan. 2021. 